\title{
Current concepts on the transmission of bacteria and parasites by blood components
}

\author{
Hospital Sirio-Libanês Blood Bank, São Paulo, Brazil
}

\begin{abstract}
Several bacterial and parasite transfusion-transmitted diseases have been described in the medical literature. This review deals with the main bacterial (Syphilis, Lyme disease, Gram positive and Gram negative agents), parasite (Chagas disease, malaria, leishmaniasis, toxoplasmosis and babesiosis) and rickettsial diseases that are carried by blood products. Preventional aspects (e.g. storage, screening tests, use of leukocyte-depleted components), diagnosis, geographical distribution and the incidence of these transfusional hazards are also discussed.
\end{abstract}

UNITERMS: Blood Transfusion. Infectious Disease. Bacteria. Protozoars. Viruses.

\section{INTRODUCTION}

I $\mathrm{n}$ this era, when viruses are the main agents of Transfusion-Transmitted Infections (TxI), one has always to keep in mind that other non-viral organisms can atso play a role in many TxI, such as bacteria and parasites.

\section{Transmission of bacteria/parasites by blood products: some common features}

There are several approaches to prevent TxI: the first one is related to an appropriate selection of blood donors based on a careful history and interview, rejecting those

\section{Address for correspondence:}

with acute diseases (e.g. fever, presence of infection at the site of venipuncture, recent dental manipulation, etc.) or belonging to high risk groups (sexual behavior, paid donors, etc.) $(1,2,3,4,5)$. In addition, a detailed physical examination may also disclose donors who might be carrying an infectious disease. Unfortunately, such measures (though effective to some degree) may not ensure an adequate level of safety, since the majority of chronic infected donors are asymptomatic, raising no doubts about their health; this has led to the use of additional serological screening (whenever possible). One has also to consider that the risk of a specific TxI may change when different geographic regions are concerned; one preventive policy may be not effective when adopted in another region or country. In summary, TxI can be prevented by an combination of different procedures:

- Adequate selection of blood donors.

- Serological screening procedures aiming at detecting the main agents from a specific region or ethnic groups.

- Proper storage and handling of blood components.

- Use of inactivation methods (e.g. physical, chemical or combined), whenever possible. 
Despite the continuous increase in safety procedures in Blood Transfusion Medicine, TxI will still be present. Its main cornerstones are:

- The donor bears a viable organism in his/her bloodstream at the time of donation.

- The agent remains active during the storage period of the blood component.

- The recipient is not infected by this same agent contained in the infected unit.

- The agent is able to induce infection once transfused into a susceptible recipient, or its presence can be detected either by direct isolation procedures or by serological markers.

- The recipient is alive at the onset of the infection.

- Other routes of transmission have been discarded.

\section{BACTERIAL CONTAMINATION}

Bacterial contamination (other than spirochetes) is still a major hazard in blood transfusion. The frequency of contamination varies according to the product studied: whole blood or packed red cells $(0.31 \%)$, random donor platelet concentrates ( 0 to $10 \%)$, single donor apheresis platelets $(0-4.9 \%)$ and frozen deglycerolized cells $(0$ $0.2 \%)(6,7)$. With the increasing use of platelet concentrates, which are kept at room temperature, this component is responsible for over $50 \%$ of Tx sepsis reported in the USA $(6,8)$. As the pre-freeze and the postthaw period for Fresh Frozen Plasma is quite short, the chances of bacterial proliferation are less than in other cellular components.

The real incidence is not known, as many cases may have gone undetected. Since many contaminated units have less than 10 microorganisms $/ \mathrm{ml}$, it is fundamental to rely on very sensitive methods for culturing. There are several factors that play a role in the incidence and detection of $\mathrm{Tx}$ sepsis, such as the storage temperature (below $0^{\circ} \mathrm{C}$, $4^{\circ} \mathrm{C}$ or $22^{\circ} \mathrm{C}$ ), the volume of blood cultured, the temperature and the culture media used for the detection, and the sensitivity of the method. Nevertheless, the incidence of contaminated products ranges from 1: 13,100 to 1:330 for red blood cells, from 1:20,000 to 1:3,600 for single donor apheresis platelets, and from $1: 10,000$ to $1: 250$ for pooled random platelet concentrates $(6,7,8,9,10)$.

Despite the utilization of stringent aseptic procedures and the use of closed systems for collection, manipulation and storage of blood products, the ever-increasing use of platelet concentrates (kept at room temperature, which facilitates bacterial proliferation) and the prolonged storage of red cells up to 42 days (ideal for the slow growth of psychrophilic organisms), have contributed to the rising incidence of $\mathrm{Tx}$ sepsis. Moreover, platelet concentrates are usually transfused to pancytopenic immunocompromised recipients unable to handle a iatrogenic infection, where up to $25 \%$ of deaths have been associated to the use of contaminated products. On the other hand, many cases may have not have been detected, as most contamination is usually minor in recipients who are receiving antibiotics for other reasons (see below).

Unfortunately, despite various efforts, no source of contamination can be ascertained in most cases. In those where a cause could be recognized, two ways of contamination are described (1):

- Exogenous - Due to the inadequate use of aseptic procedures. There are several saprophytic organisms in the donors' skin (staphylococci, streptococci, pseudomonas, diphteroids, bacilii, etc.) that may enter into the primary blood bag container when the donor's arm is not properly cleansed (11). After antisepsis, the phlebotomist must not touch the venipuncture site again. Repeated collection on scarred or dimpled sites may also result in contamination, even after antisepsis, since bacteria have been found in the deeper layer of dermis (7), and a skin plug may be formed during venipuncture, this the collection bag.

The use of non-sterile external devices (vacuum tubes for pilot samples), and solutions (e.g. saline), or the inadequate manipulation during processing (equipment in contact with blood units causing inconspicuous punctures in the bag), or even thawing in contaminated water baths are also ascribed to inducing exogenous contamination $(7,11)$.

Finally, the presence of minor cracks and leakage in blood bags or the inadequate sterilization during manufacture - as happened in Brazil in the last decade (12) and recently in Scandinavia (13) - may be responsible for external contamination.

- Endogenous - the presence of a persistent or transient asymptomatic low grade parasitemia in donors at the time of donation has also been appointed as responsible for bacterial contamination. This case may be the after dental manipulation (usually associated with staphylococci), or a gastrointestinal illness (Yersinia and Salmonella species) .

Whatever the mechanisms of bacterial penetration in blood bags are, a series of factors may prevent or enhance their growth. The first line of defense lies in the 
bactericidal properties of plasma (opsonins, complement and antibodies) and white blood cells. Other factors, such as source of nutrients in the storage medium and the competence of the inoculated bacteria to develop in a particular temperature, are also relevant issues affecting bacterial growth.

Studies where deliberately infected units were used have shown that after a lag resting phase, a log growth stage ensues, reaching more than 105 to 106 colony forming units $(\mathrm{CFU} / \mathrm{ml})$ within 3-4 days in platelet concentrates stored at room temperature, or after 20-25 days in red cells refrigerated at $40^{\circ} \mathrm{C}$.

Several microorganisms have been implicated in blood product contamination. Psychrophilic Gramnegative bacteria, capable of growing at 4o C (e.g. Salmonella, Escherichia, Pseudomonas, Yersinia species) are the main responsible agents for red cell product contamination $(7,8,11,14)$ whereas both Gram-positive and Gram-negative organisms (mainly those derived from the skin flora) have been associated with platelet contamination $(6,7,14)$.

A microorganism isolation in blood components does not necessarily mean a clinical consequence for the recipients. Many bacteria are considered as nonpathogenic (e.g. diphteroids), or show a too low concentration at the time of the infection $(<10 \mathrm{CFU} / \mathrm{ml})$ to induce signs or symptoms. Moreover, many recipients are concomitantly receiving effective antibiotics and clear this iatrogenic contamination. Clinically recognized $\mathrm{Tx}$ sepsis is recognized by the onset of high fever, rigors, chilling, nausea, vomiting, wheezing, dyspnea and tachycardia. Septic shock with hypotension, peripheral vasodilatation, hemoglobinuria, acute renal failure and disseminated intra-vascular coagulation are related to the direct infusion of endotoxin rather than the amount of transfused bacteria. In the most dramatic cases, a high rate of fatality is observed (up to $25-30 \%$ ), occurring mainly within 24-48 hours after the episode, even with the use of adequate therapeutic measures. levels:

Prevention of Tx sepsis must be performed, at several

- Collection facilities - donors must be asked about dental manipulation or gastrointestinal illness in the previous month, though this last measure is of low sensitivity and specificity. A thorough skin antisepsis and stringent aseptic venipuncture procedures must be performed, avoiding the collection in scarred areas or in repeatedly used punctures, where antisepsis may not be achieved.

- Processing units - Blood units collected in a closed system should not be violated and turned into an open system. If a unit has to be split into several aliquots, this must be done with the help of a sterile connecting device. Once the seal is broken, blood units must be used within 24 hours and discarded after this period.

Thawing of frozen products must be performed in a clean water bath, using a plastic wrapping to prevent direct contact of the units with water.

Minor defects in centrifuges, benches, baskets and any other external devices in contact with blood units may cause small undetected punctures and must be carefully controlled (11). All external solutions used for manipulation must also be sterile.

- Visual inspection - All units must undergo visual inspection before being released for transfusion, with special attention to the presence of clots (14) (the amount of citrate decreases due to its use in bacterial metabolism as a carbon source), hemolysis (15) (especially when it is present only in the blood bag and not in the attached segment), or a "pearlescent swirl" in platelet units (16).

- Inactivating agents - Antibiotics have been proposed as components of storage preservative medium; however, this measure is no longer used. Photochemical inactivation using 8-Methoxypsoralen (8MOP) and long wavelength ultraviolet light (UVA) has been proved to inactivate at least $105 \mathrm{CFU} / \mathrm{ml}$ of several bacteria, and is perhaps a promising alternative for the future (17).

- Storage period decrease - Since massive bacterial growth is usually observed after 3-4 days for platelets and 3 weeks for red blood cells, it was thought that a reduction in the storage time, e.g. 4 and 25 days respectively for these components, might diminish the likelihood of Tx sepsis. However, this measure has proved neither effective nor cost-effective $(8,18)$.

- Holding units before processing - Evidence have shown that the natural bactericidal effect present in whole blood should be greatly beneficial when collected whole blood units are stored at room temperature for 6-24 hours before being processed into components $(19,20)$.

- Pre-storage white blood cells reduction - White blood cells (WBC) play a major role in the bactericidal effect over whole blood units. Notwithstanding, some bacteria phagocytized by WBC may still survive in the cytoplasm and be released, once WBC disintegration occurs after 24 hours in refrigerated units, allowing for new bacterial growth $(20,21)$. Therefore, some authors suggested the removal of WBC by using leukodepletion filters after a "holding period". Whether WBC should be 
removed immediately before, or after processing into components is an issue under investigation $(16,21)$. It is also not quite understood whether bacterial removal occurs by reducing $\mathrm{WBC}$, or by a direct bacteria filtration effect, or both (18).

- Bacterial surveillance-Since bacterial contamination will still be present (despite all preventive measures), screening of contaminated units will decrease the possibility of transfusing a massively bacterial infected component. Several approaches have been tested and they include:

Microscopic examination: the Gram method or a cytospin smear, with acridine orange staining, has been proposed to become part of the bacterial screening for random donor platelets (pooled) or single donor platelet units older than $2-3$ days $(9,10)$. Its sensitivity is of $10^{6}$ bacteria/ $\mathrm{ml}$. However, false positive and false negative results are encountered. The method is laborious, expensive and its efficiency is still debatable (9), though a prospective study showed evidence that it might be suitable for routine screening (10).

Bacterial cultures: different results have been reported since there is no standardization as to the volume to be inoculated, the culture medium, temperature, atmosphere, time of incubation and microorganism quantification. Further more, some species require a long cultivation period, making the method useless when dealing with units that have a short storage period (e.g. platelets). Recently, the use of automated pretransfused cultures with a reduced incubation period has been introduced in many blood banks (22). It is very important to discard external contamination by confirming the initial results, whatever the method is. These preventive measures have been adopted as part of the national surveillance in some countries (7).

Blood gas analysis - with bacterial growth, $\mathrm{pCO}_{2}$ increases and $\mathrm{pO}_{2}$ decreases, both related to the size of contamination and to the gas exchange properties of the plastic used in the collection system. A study using a $\mathrm{pO}_{2}$ cut-off of 120 torr showed high sensitivity and specificity, especially for 5-day platelet units, indicating that its use may extend the storage period (23). In addition, it is possible that adhesive gas labels used as a color indicator may be developed in the near future to routinely monitor gas concentration in blood units (24).
- DNA and RNA probes - A method using a chemiluminescent acridinium-ester labeled universal bacterial ribosomal RNA (rRNA) probe, which hybridizes with bacterial nucleic acids and is revealed by a luminometer, has recently been published (23). This method is easy, fast and may be used for mass screening; its cost is anticipated to be similar to ELISA tests. Sensitivity of as low as 1 to $2 \times 10^{3} \mathrm{CFU} /$ $\mathrm{ml}$ in some and $1 \times 10^{4} \mathrm{CFU} / \mathrm{ml}$ in all deliberately infected units has been claimed, regardless of inoculum size or the collection system employed $(24,25,26,27,28)$.

- PCR - This is still a very expensive method which, although very efficient, has not been developed for routine bacteriologic screening in blood banks yet, as it is still under investigation.

\section{SYPHILIS}

Syphilis is transmitted by Treponema pallidum, a cylindrical corkscrew shaped spirochete that is easily destroyed by several factors such as: heating, low temperatures, $\mathrm{pH}$ changes, contact with water and soap; it also requires an anaerobic atmosphere for an optimal growth (29).

Since its first linkage to blood transfusion (1915), more than 200 cases have been published (many more may have been undetected or unnoticed, mainly in developing countries). However, less than 10 cases are known to have occurred in the last 30 years $(30,31,32)$.

The prevalence among blood donors, as evidenced by positive serological tests for syphilis (STS), ranges from as low as $0.004 \%$ in industrialized countries to as high as $13 \%$ in some African countries (32).

The routine use of STS in blood donors, the storage of blood components at $4^{\circ} \mathrm{C}$ or the so-called fresh components (e.g. platelets) at room temperature under aerobic conditions, usually with the concomitant application of antibiotics to recipients of these latter components, have all contributed to the dramatic decline of Tx syphilis in the last three decades. Treponema pallidum is highly sensitive to cold temperatures and storage of units at $4^{\circ} \mathrm{C}$ up to 120 hours completely destroys this spirochete. There is a direct relationship between the amount of organisms present in the blood and the time necessary to kill them $(33,34,35)$. Furthermore, a study 
using 98 units from STS positive donors in 90 recipients, which were quarantined for a minimum of 7 days at $4^{\circ} \mathrm{C}$, demonstrated the lack of disease transmission or seroconversion in all tested recipients (36); in this same study the presence of passively transfused reagins was not detected when the original titer was $<1: 8$, and in those recipients from units with a titer ranging from $1: 8$ to $1: 64$, the passively transferred antibodies were no longer detected after 10 days.

The risk of acquiring syphilis seems to be rather low. Although T. pallidum remains viable for several weeks in plasma components when stored at temperatures lower than $-20^{\circ} \mathrm{C}$, no cases have been recently described with the use of frozen components or plasma derivatives, but only with platelets or whole blood for exchange transfusion $(30,31)$.

Transmission of Tx syphilis has been seen from seronegative infected donors in the incubation period, before the onset of positive serological tests, or less likely, from those with active primary syphilis; and has not been reported from donors-presenting the secondary or tertiary phase, since they usually are symptomatic and refrain from donation. The incubation period ranges from 4 to 14 weeks (average 6-8 weeks) and is inversely proportional to the number of transfused viable organisms. There is no primary stage, with no local inflammatory lesions as observed in sexual transmission (chancre); the disease proceeds directly to the secondary stage, with general rash, fever and lymphadenopathy, thereafter following its natural course, if not treated (37).

Prevention is carried out by STS, with detection of non-specific (non-treponemal, anticardiolipin or reagins) or specific (treponemal) antibodies $(38,39)$. The former comprises : Complement Fixation Test (Wasserman), VDRL (Venereal Disease Research Laboratories) or RPR (Rapid Plasma Reagins) and the latter : FTA-Abs (Fluorescent Treponemal Antibodies absorbed with Reiter's treponema), TPHA (Treponema pallidum hemagglutination assay) or ELISA tests. Other tests are available but not used as routine procedures in serological screening. The risk of infection from seronegative donors is inversely proportional to the interval between infection and blood donation ( window period), when tests are still non-reactive, regardless of the method used. On average, treponemic tests become reactive 2 weeks after infection, with a lag phase ranging from a few days to 2-3 weeks for the appearance of reagins. Sensitivity in cases with less than 30 days, from 30 to 40 days and over 40 days of infection, is respectively $63 \%, 87 \%$ and $100 \%$ for FTAAbs, $72 \%, 80 \%$ and $100 \%$ for TPHA and $40 \%, 68 \%$ and $96 \%$ for VDRL (38). After treatment, VDRL titers usually decline, even becoming non-reactive, whereas treponemic tests will remain positive forever (serological scar).

A major problem when using non-treponemic tests is the possibility of biologically false positive results (BFP), due to cross-reaction with other diseases such as infectious mononucleosis, malaria or collagenosis. Data on BFP in developing countries range from $7 \%$ to $50 \%$ of positive STS donors, reaching $80 \%$ in industrialized regions. Although it may pose problems to blood banks, leading to the use of confirmatory tests (mainly FTA-Abs), the overall number of BFP is relatively small when compared to the absolute number of rejections by STS or to surrogate markers currently in use in blood banks (e.g. Anti-HBc or ALT). In addition, a possible association between syphilis and other diseases, mainly AIDS and hepatitis, is observed, being a possible surrogate marker (40).

With the continuing decline of Tx syphilis in the last decades, even with the increasing use of fresh components, some centers have supported the discontinuation of STS among blood donors (32). The arguments against this suggestion are: the low cost of tests even for developing countries, the identification of donors truly infected who are subsequently referred to and also investigated for other sexual contacts, or those from high risk groups for other sexually transmitted diseases (AIDS and hepatitis), which may have an additional impact on the public health system, especially in poor areas without a developed system for blood donor screening; the increase of syphilis prevalence and incidence in populations from many countries worldwide; and finally, because it is still a legal requirement in several countries $(29,34)$. Thus, despite the low risk of syphilis in blood banks, the maintenance of STS should still be regarded as a preventive measure with a major impact on the health system.

Blood units with positive STS but negative confirmatory tests are usually discarded, though the United States Food and Drug Administration Agency (FDA) accepts its use if properly labeled (41). In addition, donors with diagnosis and treatment for syphilis or gonorrhea in the last 12 months must also be deferred, since they also carry the potential risk of HIV infection.

There is a worldwide controversy about accepting recently treated donors with persistence of confirmatory tests. Blood units with positive STS for autologous purposes should be used regardless of the confirmatory results, if properly labeled; in such cases no crossingover should be accepted. Fresh units that are to be used in remote areas where tests cannot be applied must be followed by a prophylactic injection of penicillin $\mathrm{G}$ to the recipient. 


\section{OTHER TREPONEMATOSIS}

Other tropical, non-syphilitic treponematosis such as yaws (T. pertenue) and pinta ( $T$. carateum), although usually asymptomatic and exhibiting a spirochetemic phase, have not been related to blood transfusion in tropical countries $(1,39)$.

\section{LYME DISEASE}

This recently described spirochete disease presents a worldwide distribution, but the majority of cases have been seen in the USA $(42,43)$. It is caused by Borrelia burgdorferi, transmitted by the biting of several tick species, mainly of the genus Ixodes.

Blood cultures are found to be positive in 2 to $6 \%$ of patients, indicating a possibility of transfusional transmission, but all cases happened in the presence of symptoms (skin lesions, cardiac or neurologic disturbances and arthritis and musculoskeletal pains), which would defer these donors should they want to donate blood.

Deliberately inoculated blood units show a survival of $B$. burgdorferi up to 6 days in platelet concentrates, and 45 to 60 days in packed red cells and frozen plasma, though the inoculum seemed to be higher than that naturally found in the bloodstream of infected patients. In addition, 5 to $10 \%$ of patients are asymptomatic, increasing the likelihood of accepting infected donors. However, despite the theoretical risk of transfusional transmission, no cases of Lyme disease by this route have been reported so far. To further elucidate the low risk of transmission, a report from Denmark studied an infected woman who had donated blood 4 times during the remission phase of the disease and none of the 4 recipients of whole blood, plasma and packed red cells became infected or seroconverted within 6 months of follow-up (44). Therefore, it is recommended that no routine screening procedures should be adopted at the moment, but all blood bank staff should become more acquainted with this new disease. Donors who have received appropriate therapy and remained asymptomatic should also be accepted (45).

\section{RICKETTSIAL INFECTIONS}

The main human infections by Rickettsia include epidemic typhus (Rickettsia prowazekii), Q. fever (Coxiella burnetii), Rocky Mountain spotted fever ( $R$. ricketsii) and Mediterranean spotted fever ( $R$. conarii), which are transmitted through insect or tick bites, ingestion or inhalation of infected material, or, rarely, by blood transfusion, since rickettsemia precedes the onset of symptoms (headache, rash and neurologic disturbances) $(1,4,39)$.

The prevalence of antibodies against some Rickettsia amongst blood donors is much higher could be expected from the prevalence of the disease among the general population, or among recipients of blood products (46), since only two cases have been reported in the literature $(47,48)$ and, in both of them, the donors became symptomatic shortly after donation (1 to 2 weeks).

Since the risk is extremely low, no routine screening procedures are recommended.

\section{CHAGAS' DISEASE (AMERICAN TRYPANOSOMIASIS)}

Chagas' Disease (CD) is a chronic multisystemic disease caused by the flagellate Trypanosoma cruzi (49), whose natural vector is a reduviid bug (kissing bug). Distributed from Utah (USA) to Patagonia (Argentine), this disease affects 24 million people in Latin America (50).

After a blood meal, the bug defecates, leaving many infective trypomastigotes in the feces, which enter the bloodstream by local scratching or direct contact with the mucosae. After an acute phase (usuall in children but $20 \%$ of cases may be asymptomatic), the disease subsides into an indeterminate phase (asymptomatic) which can last a lifetime, or durlops into a chronic phase after several decades affecting mainly the cardiac and gastrointestinal systems $(49,51)$.

Besides transmission by insects, it can also be conveyed by transfusion of contaminated blood, organ donation, transplacentally, by breast feeding or accidentally during laboratory manipulation.

After the first Tx Chagas' Disease in 1952 (52), several cases have been described in all Latin American countries; however, less than 300 cases have been reported, clearly denoting an underreporting in these countries $(49,53,54)$. Until recently, Chagas' Disease was limited to poor rural areas or to major cities where immigration is an important occurrence in Latin America. With political turmoil and economical crisis, intense immigration movements towards developed countries 
(North America, Europe, Australia and Japan) have taken place. Currently, an estimated 3 million Latin American immigrants are now living in the USA, and 100,000 to 150,000 of them may be infected $(55,65)$.

Since acute cases are mainly seen in childhood, one could expect infected immigrants to be in the indeterminate phase without any suggestive symptoms. Furthermore, as physicians from developed countries are unaware of the clinical symptoms, it to be expected that some infected donors have been donating their blood in non-endemic areas (56). This is corroborated by the fact that three cases have been found in the USA $(4,57,58)$, one in Canada (59) and another one in Spain (60).

The prevalence of infected donors varies in Latin America countries, ranging from as low as $0.01 \%$ $(49,51,53,54)$, to as high as $60 \%$ (in certain Bolivian cities) (61). In the USA, one report from South California, where $40 \%$ of donors were of Latin American origin, found a prevalence of $0.1 \%$ to $1.1 \%$ (62), and a multicenter study with more than 7,000 donors revealed an infection rate of $0.166 \%$ among Hispanic donors (63).

The risk of becoming infected from a whole blood unit ranges from 12 to $25 \%$. T.cruzi is viable in refrigerated whole blood for over 18 days, and resists freezing conditions for at least 24 hours. Thus, all blood components are considered infectious, except blood derivatives (e.g. albumin, immunoglobulins and coagulation factors concentrates).

Regarding TxCD, about $20 \%$ of such cases are asymptomatic and fever (the main symptom during the acute phase) can be easily attributed to other causes. Only in a few patients, usually in immunosuppressed ones, are overt symptoms fully present. Thus, it is also expected that many cases may be occuring in developed countries without correct diagnosis.

Prevention of TxCD can be acheived ne by three main approaches $(53,64)$ :

- Donor history and interview - Paid donors should not be allowed. A Brazilian study carried out in the 1980 's estimated that the mere change from paid to volunteer donors led to a $70 \%$ decrease in the rate of infected blood donors. In non-endemic areas, those who have been living in infested dwellings or have been bitten by the bug must also be deferred. Specific pre-donation questionnaires have been introduced in California in order to achieve a certain safety level (65A).

- Serological screening - Several methods are available for antibody detection. Complement fixation has been gradually replaced by IHA, IIF or ELISA, of which many are available in Latin America and also recently in the USA. With the wide antigenic profile of different T.cruzi strains and the host's variable immune response, none of these methods can be regarded as $100 \%$ safe. This had led WHO to propose that at least two distinct methods should be used for blood donor screening. False positive results are due to cross-reactions with other agents as Leishmania $s p, T$. rangeli and fungi. Unfortunately, there is not a good confirmatory method, and with some donors it is highly difficult to achieve a final diagnosis based solely on serological tests. Serological markers currently in use in blood banks, even in non-endemic or industrialized countries, cannot be used as surrogate tests, no association has been found with Chagas disease (66).

- Chemoprophylaxis - Since some areas present a high prevalence of infected donors, one cannot rely on serological screening only. Furthermore, in remote areas where standard procedures are not available, chemoprophylaxis may be the sole method of preventing $\mathrm{Tx} C D$.

Though more than 1,000 chemical compounds have been tested so far, only crystal violet (gentian violet) a phenyl methane dye is effective, in a standard concentration of $1: 4000$ or $125 \mathrm{mg} / 500 \mathrm{ml}$ whole blood $(200 \mathrm{ug} / \mathrm{ml} 0.6$ $\mathrm{mmol} / \mathrm{L})$ after 24 hours of treatment $(49,67)$. The association of ascorbate $(10 \mathrm{mM})$ and light exposure (130 $\mathrm{w} / \mathrm{M}^{2}$ ) reduced to $0.4 \mathrm{mmol} / \mathrm{L}$ the trypanocydal effect after only 20 minutes of treatment $(68,69)$. Unfortunately, this drug has side effects on platelets, and it is toxic when more than $2,500 \mathrm{ml}$ of whole blood or components are transfused into an adult recipient. Nevertheless, it is highly effective when this limitation is followed.

Other agents are currently under investigation, such as phenolic antioxidants (70), gamma irradiation (71) and filtration by leukocyte filters, but they are still considered experimental.

\section{AFRICAN TRYPANOSOMIASIS}

African trypanosomiasis occurs only on the African continent and is caused by two species of trypanosomes, T. gambiensis and T. rhodesiensis, both transmitted by the bite of tse-tse flies (Glossina palpalis). Transfusional risk seems to be low, and there are few reports on the role of transfusional-transmitted African trypanosomiasis. Infection occurs mainly by $T$. gambiensis, which causes a chronic form of illness with asymptomatic periods; on 
the other hand, $T$. rhodesiensis causes a more severe and symptomatic disease which will defer donation $(1,9)$.

\section{LEISHMANIASIS}

Visceral leishmaniasis (Kala-azar) is caused by Leishmania donovani through the bite of sandflies, leading to a chronic infection with fever, anemia, lymphadenopathy and hepatosplenomegaly, and affects approximately 12 million people in tropical and sub-tropical areas. The parasite is found in the reticuloendothelial cells and in leukocytes, which can be transmitted to recipients from asymptomatic donors.

There are five cases reported in the literature, affecting mainly newborns and immunosuppressed patients $(72,73,74)$. Though very rare, donors with a history of visceral leishmaniasis must not be accepted (45).

Since Kala-azar was diagnosed in American soldiers serving in international military units, and a viscerotropic form of L. tropica was found among the military personnel who served during the Gulf War, a temporary deferral was applied in the USA until January 1993 on those returning from the Persian Gulf area, followed by the introduction of a restriction on donors who claimed to have had leishmaniasis; however, an extensive investigation carried out by the US Department of Defense failed to confirm any threat to the American supply by this viscerotropic form of $L$. tropica and these new guidelines were recently canceled (75).

\section{TOXOPLASMOSIS}

Toxoplasmosis is a zoonosis caused by Toxoplasma gondii, where felines are the definitive hosts, and birds and other mammals (including humans) are the intermediary hosts. The three forms of toxoplasmosis (trophozoites, cysts and oocysts) are found in felines, whereas only trophozoites and cysts are found in the latter. It is estimated that about 500 million people worldwide are infected by $T$. gondii with an annual incidence of new cases ranging from $1 \%$ to $5 \%$.

Infection in humans may occur by one of the following ways (39):
- Ingestion of cysts from raw or undercooked infected livestock (e.g. pork, lamb or beef).

- Accidental ingestion of oocysts after contact with infected feces from household cats, usually present in garbage or in the soil.

- Congenitally, from infected mothers to their babies.

- Direct contamination of open wounds, organ transplantation, blood transfusion or arthropod bites. There is varied evidence to support the possibility of toxoplasmosis acquired by transfusion of blood components. Fourteen months to four years after the onset of infection, the organism may be recovered from asymptomatic donors or from infected persons (76, 77, $78,79,80$ ), and is able to survive at $4^{\circ} \mathrm{C}$ for up to 50 days in citrated blood (81); furthermore, a study in thalassemia major patients who had had multiple transfusions showed a 6-time higher prevalence of toxoplasma antibodies than the age-matched controls, despite the absence of symptoms in infected recipients. Since $T$. gondii is a mandatory intracellular organism, the possibility of transmission by acellular products is remote.

The majority of infected recipients are asymptomatic; occasionally lymphadenopathy, malaise, fever, headache, cutaneous rashes and sore throat may be found, resembling a mononucleosis-like syndrome and usually unrelated to toxoplasmosis by the assistant physician. Severe cases have only been found in immunosuppressed recipients who usually received large amounts of leukocytes from chronic myelogenous leukemia donors $(78,79)$, though in one case a platelet recipient was described (82). Some patients may develop severe symptoms such as meningoencephalitis, miocarditis, hepatitis, retinochoroiditis or posterior uveitis, causing permanent injury or death.

The prevalence of infected donors varies widely ranging from $8 \%$ to $60 \%$, according to the geographical region. Approximately $18 \%$ of those with $T$. gondii antibodies have detectable IgM, indicating recent infection and $30-40 \%$ are highly titered sera (39). There is a general trend towards an increasing prevalence with age (older groups $>$ younger groups) or sex (female $>$ male in younger donors) (83).

Diagnosis - Although direct identification methods of parasites have been described, they are unsuitable for routine use in a blood bank, where as serological tests ( $T$. gondii antibodies) are more appropriate. There are several methods of detecting T. gondii antibodies (e.g. Dye exclusion test or Sabin-Feldman reaction, Complement Fixation, IHA, IIF, agglutination tests or ELISA). Since there is a high prevalence of antibodies in the general population, a seroconversion, a rising titer or the presence 
of IgM antibodies must be clearly demonstrated to show an acute infection.

Prevention - Due to the relatively low risk for recipients, except for those immunosuppressed who received large amounts of leukocytes, and perhaps negative pregnant women (though no congenital cases have been described where blood components were the only possible cause), it seems in necessary to establish routine screening procedures for all blood donations. When there is a chance of transfusing blood components to those high-risk group recipients, especially leukocytes, it seems rather prudent to establish a panel of Anti-Toxoplasma negative blood donors (83). Despite the possibility of reintroducing granulocyte transfusions with G-CSF or GM-CSF stimulation to donors in bone marrow transplants, the above measures and preventive chemoprophylaxis with sulphametoxasol/trimetroprim could be rather effective.

The role of leukocyte-depleted blood may also be considered effective, as well as blood inactivating agents (e.g. crystal violet) (84).

\section{MALARIA}

The first case of transfusional malaria (TxM) was reported in 1911, and more than 3,000 cases have been described since worldwide (85).

Human malaria is caused by four different species, Plasmodium falciparum, P. vivax, P. ovale and P. malariae, all of them requiring two different hosts to complete their evolutive cycle: a mosquito (Anopheles), where the sexual stage takes place, and humans, where the asexual stage occurs.

When infected female Anopheles mosquitoes bite humans, they release asexual sporozoites that circulate for a short time in the bloodstream, until they invade hepatocytes (exo-erythrocytic stage) and undergo an evolutive step that ends with the rupture of mature schizonts and release of merozoites in the bloodstream, which will invade red blood cells (erythrocytic stage). Another evolutive step occurs in red cells, where other merozoites are released into the bloodstream and invade other red cells, repeating this asexual phase. This process is rather regular, lasting from 48 hours for $P$. falciparum, $P$. vivax and $P$. ovale (Tertian fever) to 72 hours for $P$. malariae (Quartan fever).

Some erythrocytic parasites undergo another evolutive step and become sexual gametocytes; when released, instead of invading red cells they are ingested by a mosquito and begin a sexual reproduction in the Anopheles's stomach, forming an oocyst, which subsequently ruptures, releasing sporozoites that migrate towards the salivary gland to complete their evolutive cycle $(39,85,86)$.

In the past 40 years, malaria has been eradicated in most European countries, the United States, Japan and Australia; however, it still affects many countries worldwide, where more than 100 million individuals are infected every year, with more than 1 million deaths (87). TxM is more a consequence of the sanitary conditions of a country, when it occurs in regions where complete eradication has not been achieved, or is due to imported cases, by immigrants from endemic areas or travelers returning to non-endemic regions.

The incidence of TxM ranges from as low as 0.25 cases/million units transfused (USA, UK), to more than 50 cases/million in some endemic areas $(87,88)$. Even in non-endemic countries, where eradication is complete, it varies according to the migratory flow that took place in the last three decades; this is particular true in France, where more than 100 cases were detected during the 1980's (89).

Infected blood donors may harbor parasites for many years, especially when they are from endemic regions where immunity renders a somewhat absence of symptoms. Different periods of infection are seen for each species; it is widely known that $P$. falciparum can be cleared within one year, although longer periods ( $8-13$ years) have been described. $P$. vivax and $P$. ovale usually do not persist for more that 3-4 years, but infections after 6-8 years or even longer have also been described. However, longer periods of longevity ranging from 10 to 50 years were seen for $P$. malariae, as reported in the former USSR and in the USA $(87,88,90)$. Although exceptions exist, $P$. falciparum, $P$. ovale and $P$. vivax, it seems unlikely that a donor will remain infective after five years of infection, which is the basic element for questioning blood donors (see below).

TxM is transmitted through asexual forms that are limited to red blood cells, usually from asymptomatic donors who carry a low parasytemic level, and rarely in the period between the subclinical parasitemia and the onset of symptoms (usually associated to previous chemoprophylaxis). Transmission from symptomatic donors is very unlikely, and when present it usually occurs in endemic regions.

The minimum amount of parasites that leads to infection is not known; for P. vivax, a total of 10 parasites/ $\mathrm{ml}$ was successful in inducing experimental transmission (87). 
Though transmission occurs mainly through the use of red cells products (whole blood or packed red cells), all components with contaminating cells are infectious (fresh plasma, platelets and granulocyte concentrates). They remain infective even in glycerolized post- thaw units preserved at $-70^{\circ} \mathrm{C}$. No infection has been associated with freeze-dried plasma or industrialized derivatives (albumin, immunoglobulin, etc.).

Though viability at $4-6^{\circ} \mathrm{C}$ storage is less than five days for $P$. malariae and up to 10 days for $P$. falciparum, holding units for 7-10 days in order to achieve a relative protection is not justified.

A survey covering the $1950-72$ period showed that P. malariae was responsible for $48 \%$ of cases, $P$. vivax for $19 \%$, P. falciparum for $5 \%, P$. ovale for very few cases and in $30 \%$ the species could not be determined. However, during the $1973-80$ period, the distribution was $38 \%$ for P. malariae, $42 \%$ for $P$. vivax and $P$. ovale, and $20 \%$ for $P$. falciparum (87).

The incubation period depends on several factors: the number of viable transfused parasites; the species and the strain, the host immunity, and the previous use of malarial chemoprophylaxis. On the average, TxM has a longer incubation period than that observed in natural transmission, with a 16-day mean period (8-29 days) for $P$. falciparum, a 19.6-day mean period (8-30 days) for the $P$. vivax and the $P$. ovale, and a 57.2-day mean period (6106 days) for the $P$. malariae (85).

In the beginning, the symptoms are usually nonspecific, mainly fever that only turns into its peculiar periodicity within 2 weeks. Since most physicians in nonendemic areas are unaware of this possibility, a period is observed between the onset of the symptoms and the diagnosis, ranging from 12 to 43 days, but periods of 160 days or even one year have been reported. Even in endemic countries, a long delay can be observed (91). Symptoms are more severe in splenectomized, organ transplants or immunodefficient recipients.

The rate of lethal cases is highly related to delay in diagnosis (especially in non-immune recipients) and plays an important role when infection is due to $P$. falciparum (with cerebral, renal and pulmonary lesions). What was particularly striking in the USA after the Vietnam war, when a 24 times higher mortality was seen in patients diagnosed in civilian hospitals, compared to that from military hospitals (39). Fatalities are still high, with some reports of up to $20 \%$ of cases, higher than the imported cases $(<1 \%)$, maybe because TxM in developed countries affects non-immune recipients. Thus, we must always bear in mind this possibility when fever ensues after a transfusional episode. Since no exo-erythrocytic stage is observed in TxM, no relapse is found (irrespective of the causative species) after appropriate treatment. Diagnosis is supported by clinical findings and by the presence of circulating parasites. Thick smears are to be done every 8 hours during 2-3 days by an experienced technician, followed by serological tests (which are usually positive when symptoms are present). Adequate identification of the species and immediate treatment are important; when identification is not possible, it is advisable to treat the patient as having a $P$. falciparum infection.

A dramatic decrease in TxM should be expected after malaria eradication in the USA. However, due to successive wars, American troops, when returning from Korea, Vietnam (and lately from Somalia), brought back a remarkable number of infected personnel, although preventive measures were adequately taken, responsible for TxM in USA. On the other hand, migratory movements, particularly from Africa and India into Europe, and from Southeastern Asia and South America into North America (92), are also responsible for TxM. Therefore, specific measures should be taken in order to prevent it.

The first one is an accurate history including place of birth, previous residence places during lifetime, immigration, and a complete account of prior traveling during the past three years. The use of specific questionnaires aims at excluding three types of infected donors:

- non-immune travelers who acquired malaria abroad, preventing relapses after specific treatment $(P$. vivax and $P$. ovale), or asymptomatic parasitemia following inadequate chemoprophylaxis.

- military personnel returning from endemic areas.

- foreign visitors or immigrants from endemic regions who are usually immune and asymptomatic.

Though legislation in different countries varies (45, 93), blood donors should not be accepted until six months after chemoprophylaxis has been finished, in the absence of symptoms. Those with alleged infection in the past, or who had taken chemoprophylaxis in the presence of symptoms, should not accepted during a 3-year period. This measure is highly effective for $P$. falciparum, $P$. vivax and $P$. ovale, but not for $P$. malariae, for which longer periods of infectivity have been recorded. The questionnaires are valid only for products where viable red cells are present, but may be disregarded for donations intended exclusively as sources for plasma fractionation. Since the world malarial zone is too vast, an alphabetical list of countries reporting malaria transmission and a geographical malarial map (provided by WHO) should be present in every collection facility. Unfortunately, 
preventing infected donors only by questionnaires brings two additional problems (94):

- Low specificity, thus rejecting a somewhat high number of healthy donors. A recent study in the USA (95), where the incidence of TxM is 0.25 cases/ million units, claims that by reducing the interval to 6 months after travel, irrespective of prophylaxis, some 70,000 to 315,000 additional blood units could be collected a year with an additional calculated risk of 0.03 cases/million units in the annual incidence. The authors stated that the 6-month deferral was accurate for $88 \%$ of cases, and the 3-year deferral period used for preventing $P$. vivax and $P$. ovale (which accounted for only $33 \%$ of cases) would have prevented only one case in 17 years.

- Low sensitivity - After a careful examination of all cases of TxM in the USA, it was stated that at least $50 \%$ of them could be avoided if the aforementioned questionnaire were correctly filled out (95). The interviewer has also to rely upon the accuracy of the donors' history, which may be fallible in most cases. This same study reported that a positive history could be ascertained in only $20-30 \%$ of the implicated donors, since many of them had been infected in childhood, or did not even remember the episode.

Because of these problems, some countries have introduced a specific serological screening (see below), which is applicable only to selected suspected donors, such as immigrants or individuals born in endemic areas, or those who have had malaria at least three years before donation $(89,93)$. With this strategy, about $10 \%$ of those tested were confirmed as infected, saving many units that would have been otherwise rejected.

Other more radical positions, such as the permanent exclusion of all persons born or also having lived in endemic areas have been proposed, but they should be carefully analyzed, especially in places with a shortage of blood units (96).

In countries where malaria is endemic, the exclusion of donors previously infected for three years may be unsuitable; in addition, the use of some screening tests, such as the thick smear or the detection of malarial antibodies may also be inadequate, since most cases show only a previous infection and not the presence of circulating parasites. In such cases, it seems that testing for malarial antigens with monoclonal antibodies may be satisfactory (97).

On the other hand, in remote areas where it is virtually impossible to rely solely upon uninfected donors, where neither screening tests are available or adequate blood collection facilities are present, the following procedures are recommended:
- Exclude candidates with a febrile episode in the last 30 days. This procedure has been used with partial success in the Amazon's highly endemic areas in Brazil.

- Introduce the use of chloroquine by donors, 48 hours before donation or a single shot immediately before, and then accept donation. This measure usually goes together with preventive chemoprophylaxis for the recipient, who must be continuously treated for a month. Unfortunately, preventive chemoprophylaxis for recipients is not advisable for pregnant or breastfeeding women or for infants, and is ineffective for drug-resistant $P$. falciparum strains, which are responsible for the worst cases $(39,87)$. Furthermore, such measures should not be taken into account when recipients are from non-endemic regions (nonimmune).

The use of inactivating agents such as merocyanine 540 (with photoirradiation) (98), or crystal violet (99) are under current investigation.

Screening tests aimed at the detection of circulating antibodies or antigens $(87,89,100)$, are:

- Detection of antibodies - Based mainly on IIF, IHA or ELISA, using $P$. falciparum, non-human parasites (that show some cross-reactivity with human antibodies), purified or recombinant antigens. These tests are useful to interpret high titered or negative sera, denoting respectively the presence or absence of infection. However, in patients with low titered sera, in most cases, the test must be supplemented by a thorough interview with the donor (92). However, the presence of antibodies does not necessarily mean that circulating parasites are present. Antibodies usually appear one week after the onset of the infection for $P$. falciparum (with longer periods for other species), and are positive in $>96 \%$ of infected donors, being highly effective for $P$. malariae, where a long latency period and high titers are found. They disappear within 6 months after a successful treatment.

- Detection of antigens - The easiest one is the thick smear test, however it lacks sensitivity, with a limit of 100 parasites $/ 1$, which is more than the minimum necessary for transmission; it is also highly subjective and cannot be used as a mass screening method. One study showed prevention by thick smear in only $10 \%$ of TxM, and positivity in $31 \%$ $(8 / 26)$ of donors implicated in TxM in the USA (95). The detection of parasites within erythrocytes, or of soluble antigens, has been achieved by RIA, ELISA or IIF, the latter mainly in endemic countries (86). Sensitivity reaches 5-30 parasites/l; however lower levels of 
parasitemia may reach up to $2.5 \times 10^{6}$ parasites in one unit of blood (87). Recently, the detection of parasites in the bloodstream using the automatic acridine orange dye test (QBC system) has gained use in the Amazon region. Other tests, such as DNA probes or PCR, are not adequate for blood donation yet.

A great deal of concern still exists related to the rising possibility of TxM, and the reasons can be summarized as follows (92): asymptomatic individuals from endemic areas are increasingly traveling to non-endemic regions (e.g. immune donors to a group of non-immune recipients); the atypical incubation period (from 6 to $>60$ days) is easily misdiagnosed; the unawareness of attending physicians in most non-endemic countries, who may additionally be unable to arrive of an accurate diagnostic when inadequate malarial chemoprophylaxis is taken (that may change TxM natural evolution); the ever increasing appearance of drug-resistant strains, particularly of $P$. falciparum, which cause the most severe cases; the resurgence of malaria in areas where it had already been previously eradicated from, and finally, the settlement of individuals in prior uninhabited and virgin areas, mainly in South America, with a dramatic increase of vector transmitted malaria.

\section{BABESIOSIS}

Babesiosis occurs in animals and humans, caused by parasites of the genus Babesia. There are 71 species in nature, but only two affect humans: Babesia bovis in Europe and Babesia microti in North America. Like Lyme disease, it is transmitted by the tick vector Ixodes dammini (USA) or Ixodes ricinus (Europe). It is widely distributed in Europe and North America, mainly in the northeastern USA. All transfusion-transmitted cases have been described in the USA so far $(43,101,102)$.

Babesia microti is a pear-shaped, oval or round parasite, $1-5 \mathrm{um}$ in length, that only reproduces in the red cells, being easily misdiagnosed as Plasmodium falciparum. The life cycle of Ixodes is quite complex and involves a larval and a nymphal stage, both feeding mainly upon the white-footed mouse ( the main natural reservoir) , and an adult phase that feeds upon the white-tailed deer, which does not become infected, serving only as a blood meal source.

Infection to humans occurs only by biting during the infected nymphal stage, and the risk of infection is related to the infestation degree of animals parasitized by the tick, which in turn, depends on the white-tailed deer population. Clinical symptoms begin 1-4 weeks after exposure to $B$. microti, with fever, chills, headache, hemolytic anemia and hemoglobinuria, in many cases resembling malarial infection. However, most infections are asymptomatic or sub-clinical and self-limited in $60-65 \%$ of cases.

Infected donors may remain asymptomatic for as long as one year. In addition, the parasite can resist at $4^{\circ} \mathrm{C}$ for up to 35 days or to freezing conditions for years. The prevalence of B. microti antibodies among blood donors ranges from 3.5 to $4.7 \%$ in the northeast of the USA. There are at least eight cases described in the literature, most of them in immunocompromised patients and one of them fatal. Previous splenectomy plays a major role in the development of the illness, since it was present in four cases. In these cases, the incubation period varied from four to eight weeks, apparently longer than in the naturally acquired disease.

Diagnosis is based on: identification of intraerythrocyte parasites in the bloodstream (more often found in hemolytic episodes); by infecting hamsters intraperitoneally with blood, or by identification of $B$. microti antibodies, mainly by IIF. Titers higher than 1:64 denote recent infection.

Prevention can be carried out by indirect and direct measures. The former includes evaluation of the donor's health, temperature or hemoglobin level that will detect symptomatic donors and have little predictive value, since $60-65 \%$ of infected donors are asymptomatic, while the latter is performed by specific screening tests in suspected donors. However, routine screening procedures for all blood donors are not recommended at present.

Unfortunately, other measures such as additional questionnaires focusing on tick bites, or blood collection avoidance in endemic areas are of limited value. Clinicians must be aware that the disease can be easily mistaken for malaria and informed that, once a case is identified, the patient must be thoroughly investigated, including previous donations. Recipients must be recalled and accurately studied. Donors who have to an history of previous infection must be permanently deferred (45).

Several facts evidence the possibility of a babesiosis increase in the USA: a broadening range of $I$. dammini infestation due to the increasing population of its hosts (mice and deer), associated with a metropolitan area expansion, since suburban dwellers have greater chances of being exposed to infected ticks, certainly leading to an increase in asymptomatic infected donors; the progressive increase in transfusions given to immunocompromised recipients, and finally, the awareness of this disease among 
the attending physicians, allowing for more diagnosed cases.

\section{FILARIASIS}

Filariasis is caused by eight different nematodes, with a worldwide distribution. However, only five of them produce microfilaremia $(4,39)$, with the ability of being transmitted from infected donors: Brugia malayi (Southeast Asia), Loa loa (Africa), Wurchereria bancrofti (Africa, Asia and Latin America), Mansonella ozzardi (Central and South America, West Indies) and Mansonella perstans (Acanthocheilonema perstans - Africa, Guyana and New Guinea).

When infected patients are bitten by a susceptible arthropod vector (e.g. mosquitoes and flies), microfilaria undergo their evolutive cycle. When they reach the infective larva stage, they will be transmitted to a noninfected human during a blood meal. Since vectors play a fundamental role in the infective cycle, transfusion of microfilaria by blood products will not lead to a permanent infective status in the host.

The prevalence of infected donors is far from being well-known, but one study with 408 donors in Zambia (103) found a rate of $5.1 \%$ and $0.2 \%$ respectively for $A$. perstans and $W$. bancrofti. Though infected blood donors are found mainly in endemic regions, it is also possible to find them in non-endemic countries due to immigration or casual infection during travel $(104,105)$.

Survival of microfilaria in stored blood at $4-6^{\circ} \mathrm{C}$ ranges from 12-14 days ( $W$. bancrofti) to $>21$ days ( $\mathrm{Loa}$ loa). Once transfused into a recipient they show different endurance periods in the bloodstream, namely: Loa loa (4 days) (105); W. bancrofti ( $<5$ weeks) (106); M. ozzardi (2 years) (107) and A. perstans (3 years) (39). Transmission occurs by infusion of liquid products (e.g. red blood cells) with no data about frozen components (FFP or cryoprecipitate),

The majority of recipients are asymptomatic when transfused with microfilaria, but experimental infections caused fever or allergic symptoms, though there are doubts whether they derived from infusion of living parasites. Nonetheless, symptoms are self-limited and vanish shortly after.

Diagnosis is made by the presence of microfilaria in the bloodstream, either by direct staining of a blood smear through concentration methods (Knott technique) or by serological tests (IHA, IIF or Flocculation).

Since transmission of microfilaria from blood components is quite rare and there is no permanent risk to the infected, recipients screening procedures are not recommended, though one should not accept an infected blood donor. In addition, the current measures to prevent $\mathrm{Tx}$ malaria are also effective to prevent TxM Filariasis.

\section{RESUMO}

Introdução: Embora as infecções virais (Hepatite B e C, retroviroses - como o HIV e HTLV - e citomegaloviroses) sejam as infecçōes mais comumente transmitidas por intermédio de produtos e componentes hemoterápicos, várias infecçōes bacterianas e parasitárias também podem ser adquiridas por estavia. Material e Métodos: Esta revisâo inclui as principais entidades bacterianas (Sífilis, Doença de Lyme e bactérias Gram-positivas e Gram-negativas), parasitárias (Doença de Chagas, leishmaniose, toxoplasmose, malária e babesiose) e riquetsioses capazes de transmissăo transfusional. Os principais meios de prevenção (conservação dos diversos componentes hemoterápicos, testes laboratoriais de triagem e detecção, filtração de leucócitos), diagnóstico, assim como a distribuiçāo geográfica e incidência transfusional são discutidos neste artigo. 


\section{REFERENCES}

1. BARBARA, J.A.J. - Transfusion-Transmitted Infections: Epidemiology relevant to blood safety. In Rock, G.; Seghatchian, M.G. (eds) - Quality assurance in Transfusion Medicine - Vol. I, pp 419-444; CRC Press Boca Raton - USA, 1992.

2. BARBARA, J.A.J. - Challenges in Transfusion Microbiology. Transf Med Rev 7: 96-103, 1993.

3. REESINK, H.W. - How far shall we go in the pre-donation selection of blood donors to safeguard patients for bloodtransfusion-related infections (Editorial). Vox Sang 65: 19, 1993.

4. SHULMAN, I.A. - Parasitic infections; an uncommon risk of blood transfusion in the United States (Editorial). Transfusion 31: 479-480, 1991.

5. STARKEY, J.M.; MACPHERSON, J.L.; BOLGIANO, D.C.; SIMON, E.R.; ZUCK, T.F. \& SAYERS, M.H. Markers for Transfusion-Transmitted disease in different groups of blood donors. JAMA 262: 3452-3454, 1989.

6. SAZAMA, K. - Reports of 355 transfusion-associated deaths, 1976 through 1985. Transfusion 30:583-90, 1990.

7. GOLDMAN, M. \& BLAJCHMAN, M.A. - Blood product associated bacterial sepsis. Transf Med Rev V: 73-83, 1991.

8. HOPPE, P.A. - Interim measures for detection of bacterially contaminated red cell components . (Editorial) Transfusion 32:199-201, 1992.

9. BARRETT, B.B.; ANDERSEN, J.W. \& ANDERSON, K.L. - Strategies for the avoidance of bacterial contamination of blood components. Transfusion 33:228-33, 1993.

10. YOMTOVIAN, R.; LAZARUS, H.M.; GOODNOUGH, L.T.; HIRSCHLER, N.V.; MORRISEY, A.M. \& JACOBS, M.R. - A prospective microbiologic surveillance program to detect and prevent the transfusion of bacteriallycontaminated platalets. Transfusion 33:902-9, 1993.

11. PUCKETT, A.; DAVISON, G.; ENTWISTLE, C.C. \& BARBARA, J.A.J. - Post transfusion septicaemia 198089: importance of donor arm cleansing. J Clin Pathol 45:155-7, 1992.

12. WENDEL, S. \& RUSSO, C. - Controle de qualidade em bolsas de coleta nacionais. Bol SBHH VIII (138) 75-6, 1986.

13. HELTBERG, O.; SKOV, F.; GERNER-SMIDT, P.; KOLMOS, H.J.; DYBJÆR, E.; GUTSCHIK, E.; JERNE, D.; JEPSEN, O.B.; WEESCHER, M.; FREDERIKSEN, W. \& SØRENSEN, H. - Nosocomial epidemic of Serratia marcescens septicemia ascribed to contaminated blood transfusion bags. Transfusion 33:221-27, 1993.

14. MOLLISON, P.L.; ENGELFRIET, C.P. \& CONTRERAS, M. - Blood Transfusion in Clinical Medicine - 9th Ed, Blackwell Scientific Publications - Oxford, 1993.

15. KIM, D.M.; BRECHER, M.E.; BLOND, L.A.; ESTES, T.J.; CARMEN, R.A. \& NELSON, E.J. - Visual identification of bacterially-contaminated red cells. Transfusion 32:221-5, 1992.

16. WENZ, B.; CIAVARELLA, D. \& FREUNDLICH, L. Effect of prestorage white cell reduction on bacterial growth in platelet concentrates. Transfusion 33:520-3, 1993.

17. LIM, L.; LONDE, H.; JANDA, M.; HARSON, C.V. \& CORASH, L. - Photochemical inactivation of pathogenic bacteria in platelet concentrates. Blood, 82(Suppl.1):205 a, Abstract 805, 1993.

18. AUBUCHON, J. \& PICKARD, C. - White cell reduction and bacterial contamination. Transfusion 33: 533-4, 1993.

19. PIETERSZ, R.N.I.; REESINK, H.W.; PAUW, W.; DEKKER, W.J.A. \& BUISMAN, L. - Prevention of Yersinia enterocolitica growth in red-blood-cell concentrates. Lancet 340: 755-6, 1992.

20. HEAL, J.M. \& COHEN, H.J. - Do white cells in stored blood components reduce the likelihood of post-transfusion bacterial sepsis? (Editorial) Transfusion 31:581-3, 1991.

21. HÖGMAN, C.F.; GONG, J.; ERIKSSON, L.: HAMBRAEUS, A. \& JOHANSSON, C.S. - White cells protect donors blood against bacterial contamination. Transfusion 31:620-6, 1991.

22. SOETERBOEK, A.M.; VON HEGEDUS, H.Y. \& VAN NOORD, P.A.H. - Blood product sterility monitoring in a blood bank. Transfusion 33 (Suppl.):Abstract S18, 1993.

23. BRECHER, M.E.; BOOTHE, G, \& KERR, A. - The use of a chemiluminescence linked universal bacterial ribosomal RNA gene probe and blood gas analysis for the rapid detection of bacterial contamination in white-cellreduced and non-reduced platelets. Transfusion 33:45057, 1993.

24. ARPI, M.; BREMMELGAARD, A.; ABEL, Y.; OLSSON, K. \& HANSEN, L. - A novel screening method for the detection of microbial contamination of platelet concentrates - An experimental pilot study. Vox Sang 65:335-6, 1993.

25. HOGAN, J.; NINTEMAN, T.; KURAMOTO, K.; KEMPER, M.; PINEDA, A.; HALLIG, V.; TEGTMEIER, G.; HENDERSON, S.; JACOBS, M. \& BAJAKSOUZIAN, S. - Detection of bacteriallycontaminated red blood cell units with an all-bacterial DNA probe test. Transfusion 33(Suppl.):Abstract S153, 1993.

26. BRECHER, M; WILLIAMS, N.; KERR, A. \& BOOTHE, G. - Comparison of two sampling methods in bacterially contaminated platelets with a RNA chemiluminescent linked probe. Transfusion 33(Suppl.):Abstract S154, 1993.

27. CHANGOKOLWATANA, V.; MORGAN, M.; FEAGIN, J.C.; JACOBS, M.R. \& YOMTOVIAN, R. - Comparison of microscopy and a bacterial DNA probe for detecting bacterially contaminated platelets. Transfusion 33 (Suppl.):Abstract S191, 1993.

28. KEMPER, M. \& KURAMOTO, K. - Rapid detection of bacterial contamination in blood and blood components. Transfusion 33 (Suppl.):Abstract S196, 1993. 
29. SEIDL, S. - Syphilis screening in the 1990's (Editorial). Transfusion, 30:773-774, 1990.

30. CHAMBERS, R.W.; FOLEY, H.T. \& SCHMIDT, P.J. Transmission of syphilis by fresh blood components. Transfusion, 9:32-34, 1969.

31. RISSEEUW-APPEL, I.M. \& KOTHE, F.C. - Transfusion syphilis: a case report. Sex.Trans.Dis., 10:200-201, 1983.

32. International Forum: Does it make sense for Blood Transfusion Services to continue the time-honoured syphilis screening with cardiolipin antigen? Vox Sang, 41:183-192, 1981.

33. GARRETTA, M.; PARIS-HAMELIN, A.; MULLER, A. \& VAISMAN, A. - Syphilis et transfusion sanguine. Rev Franc Transf Immunohematol, 20:287-308, 1977.

34. De Schryver, A. \& Mateus, A. - Syphilis and blood transfusion: a global perspective. Transfusion, 30:844$847,1990$.

35. VAN DER SLUIS, J.J.; TEN KATE, F.J.W.; VOZEVSKI, V.D.; KOTHE, F.C.; AELBERS, G.M.N. \& VAN EIJK, R.V.W. - Transfusion syphilis, survival of Treponema pallidum in stored donor blood - II - Dose dependance of experimentally determined survival times. Vox Sang 49:390-9, 1985.

36. WALKER, R.M. - The disposition of STS Reactive Blood in a Transfusion Service. Transfusion, 5:452-456, 1965.

37. CHATAING, B. - Intérêt du dépistage sérologique de la syphilis à l'occasion des dons du sang (ou prévention de la syphilis transfusionelle). Rev Franc Transf Immunohematol 31:73-79, 1988.

38. HART, G. - Syphilis tests in diagnostic and therapeutic decision making. Ann Inter Med 104:368-376, 1986.

39. TABOR, E. - Infectious complications of blood transfusion. Academic Press, New York - USA, 1982.

40. RAMSEY, G.; SOLTIS, F.; BOWMAN, R.; MCNAMARA, J.; HAHN, L.F. \& DIXON, B.W. Syphilis serology in blood donors: a possible surrogate marker for human immunodeficiency virus. Vox Sang., 60:165-168, 1991 .

41. Anonymous - FDA clarifies syphilis screening recommendations. Blood Bank Week, 8,(46):1-3, 1991.

42. AOKI, S.K. \& HOLLAND, P.V. - Lyme disease - another transfusion risk? Transfusion, 29:646-650, 1989.

43. POPOVSKY, MA - Babesiosis and Lyme disease: a transfusion medicine perspective. In: Westphal, R.G.; Carlson, K.B. and Turc, J.M. (eds): Emerging Global patterns in Transfusion-transmitted Infections. Arlington, VA, AABB, USA, p.45-64, 1990.

44. SORENSEN, L.H.; KRAGBALLE, K.; NEDERGAARD, S.T. et al. - Lack of transmission of Borrelia burgdorferi by blood transfusion. Lancet, 1:550, 1990.

45. Standards for Blood Banks and transfusion services AABB Bethesda MD, USA. 15th ed., 1993.

46. RAOULT, D.; TOGE, B.; CHAUdET, H. \& CHICHEPORTICHE, C. - Rickettsial antibody in Southern France: antibodies to Rickettsia conorii and Coxiella burnetti among urban, suburban and semi-rural blood donors. Trans R Soc Med Trop Hyg, 81:80-81, 1987.

47. GOLDBERG, J.J.; PERKINS, H.A. \& ZEPITZ, U.M. - Q fever. MMWR 26:86-91,1977

48. WELLS, G.M.; WOODWARD, T.E.; FISET, P. \& HARNICK, R.B. - Rocky Mountain Spotted Fever caused by blood transfusion. JAMA 26:2763-65, 1978.

49. WENDEL, S.: BRENER, Z.; CAMARGO, M.E. \& RASSI, A. (eds). Chagas' Disease (American Trypanosomiasis); its impact on transfusion and clinical medicine. ISBT, Brasil '92, SBHH, 1992.

50. HAYES, R.J. \& SCHOFIELD, C.J. - Estimación de las tasas de incidencia de infecciones y parasitosis crónicas a partir de la prevalencia: La enfermedad de Chagas en America Latina. Bol Of Sanit Panam 1990;108:308-316.

51. WENDEL, S. \& GONZAGA, A.L. - Chagas disease and blood transfusion: a new world problem? Vox Sang, 64:112, 1993.

52. FREITAS, J.L.P.; AMATO, V.; SONNTAG, R.; BIANCALANA, A.; NUSSENSZWEIG, V.\& BARRETO, J.G. - Primeiras verificacōes de transmissão acidental da molestia de Chagas ao homem por transfusão de sangue. Rev Paul Med 1952;40:36-40

53. DIAS, J.C.P. \& BRENER, Z. - Chagas' disease and blood transfusion. Mem Inst Oswaldo Cruz 1984;79:139-147.

54. SCHMUÑIS, G.A. - Trypanosoma cruzi, the etiologic agent of Chagas' Disease: status in the blood supply in endemic and non endemic countries. Transfusion 31:547-57, 1991.

55. KIRCHHOFF, L.V. \& NEVA, F,A. - Chagas' disease in Latin American immigrants. JAMA 1985;254:3058-60.

56. WENDEL, S.- Chagas' Disease: an old entity in new places (Editorial) Int J Art Organs, 16:117-119, 1993.

57. GEISELER, P.J.; ITO, J.I.; TEGTEMEIER, B.R.; KERNDT, P.R. \& KRANCE, R. - Fulminant Chagas' disease in bone marrow transplantation. 27th Intersc Conf on Antimicro Agents and Chemoter. Washington Am Soc for Microbiol (Abstract) 1987:418.

58. GRANT, I.; GOLD, J.W.H.; WITTNEE, M. et al. Transfusion associated acute Chagas' disease acquired in the United States. Ann Intern Med 1989;111:849-51.

59. NICKERSON, P.; ORR, P.; SCHOEDER, M.C.; SEKLA, L. \& JOHNSON, J. - Transfusion associated Trypanosoma cruzi infection in a non endemic area. Ann Inter Med 1989;111:851-3.

60. VILLALBA, R.; FORNÉS, G.; ALVAREZ, M.A.; ROMÁN, J.; RUBIO, V.; FERNANDEZ, M.; GARCIA, J.M.; VIÑALS, M. \& TORRES, A. - Acute Chagas' disease in a recipient of a bone marrow transplant in Spain: case report. Clin Inf Dis 14: 594-95, 1992.

61. ZUNA, H.; RECACOECHEA, M.; BERMUDEZ, H.; ROMERO, A. \& CASTEDO, J. - Transmissión de la enfermedad de Chagas por via transfusional en Santa Cruz de la Sierra, Bolivia. Bol Inf CENENTROP 5:49-56, 1979.

62. KERNDT, P.R.; WASKIN, H.A.; KIRHHOFF, L.V. et al. Prevalence of antibody to Trypanosoma cruzi among blood 
donors in Los Angeles, California. Transfusion 31:814-8, 1991.

63. PAN, A.A.; BRASHEAR, J.; SCHUR, J.D. et al. Prevalence study and confirmation of seropositive antibodies to Trypanosoma cruzi (Chagas' Disease) in Hispanic and Non-Hispanic blood donors in the United States. Rev Paul Med 110(5): suppl. Abstract TTD-18, 1992.

64. WENDEL, S. - Blood Banking preventive approaches for Chagas' Disease. Mem Inst Oswaldo Cruz, 88(suppl.):59. 60, 1993.

65. KIRCHHOFF, L.V. - Trypanosoma cruzi: a new threat to our blood transfusion supply (editorial). Ann Intern Med 111:773-775, 1989.

65A.APPLEMAN, M.D.; SHULMAN, I.A.; SAXENA, S. \& KIRCHHOFF, L.V. - Use of a questionnaire to identify potential blood donors at risk for infection with Trypanosoma cruzi. Transfusion 33: 61-4, 1993.

66. WENDEL, S. \& BIAGINI, S. - Absence of surrogate serologic marker for Trypanosoma cruzi infected donors: a retrospective analysis. Transfusion 33 (Suppl); S156, 1993.

67. NUSSENSZWEIG, V.; SONNTAG, R.; BIANCALANA, A. et al. - Acão dos corantes trifenilmetanicos sobre o Trypanosoma cruzi in vitro. Emprego da Violeta de Genciana na profilaxia da transmissão da molestia de Chagas por transfusão de sangue. O Hospital 44:731-744, 1953.

68. DOCAMPO, R.; MORENO, S.N.J. \& CRUZ, F. Enhancement of the cytotoxicity of crystal violet against Trypanosoma cruzi in the blood by ascorbate. Mol Biochem Parasitol 27:241-248, 1988.

69. SOUZA, H.M. - The present state of chemoprophylaxis in transfusional Chagas' Disease (editorial) Rev Soc Bras Med Trop 22:1-3,1989.

70. LETELIER, M.E.; RODRIGUES, E.; WALLACE, A.; LORCA, M.; REPETHO, Y.; MORILLO, A. \& ALDUNETI, J. - Trypanosoma cruzi: a possible control of transfused induced Chagas' Disease by phenolic antioxidants. Exp Parasitol 71:357-363, 1990.

71. TAKEDA, G.K.F.; CAMPOS, R.; KIEFFER, J. et al - Acão de raios gama sobre formas sanguicolas de Trypanosoma cruzi. Estudo experimental em camundongos. Rev Inst Med Trop São Paulo 28:15-18, 1986.

72. CHUNG, H.L.; CHOW, K.K. \& LU, J.P. - The first two cases of transfusion Kala-azar. Clin Med J, 66:325-26, 1948.

73. ANDRE, R.; BRUMPT, L. \& DREYFUS, B. - Cutaneous leishmaniasis, cutaneous glandular leishmaniasis and trasfusional Kala-azar. Trop Dis Bull 55:379, 1958

74. KOSTMAN, R.; BARR, M.; BENGTSSOM, E.; GARNHAM, P.C.C. \& HULT, G. - Kala-azar transferred by exchange blood transfusion in two Swedish infants. Proceeding of the Seventh International Congress of Tropical Medicine and Malaria, 2:384, 1963.
75. Anonymous - Defense Department drops question on leishmaniasis for blood donor. Blood Bank Week 10 (45):4-5, 1993.

76. PRIER, J.A.; COLE, C.R.; DOCTON, F.L.; SASLAW, S. \& CHAMBERLAIN, J.M. - Toxoplasmosis - Report of three cases with particular reference to asymptomatic toxoplasma parasitemia in a young woman. Arch Intern Med 92: 314-20, 1953.

77. AMATO NETO, V.; COTRIM, J.X.; LAUS, W.L. \& GOMES, M.C.O. - Nota sobre o encontro de Toxoplasma gondi em sangue destinado a transfusão. Rev Inst Med Trop São Paulo 5: 68-9, 1963.

78. ROTH, J.A.; SIEGEL, S.E.; LEVINE, A.S. \& BERARD, C.W. - Fatal recurrent toxoplasmosis in a patient initially infected via a leukocyte transfusion. A J C P 56: 601-5, 1970.

79. SIEGEL, S.E.; LUNDE, M.N.; GALDERMAN, A.H.; HOLTERMAN, R.H.; BROWN, J.A.; LEVINE, A.S. \& GRAW JR., R.G. - Transmission of Toxoplasmosis by leukocyte transfusion. Blood 37: 388-394, 1971.

80. RÄISÄNEN, S. - Toxoplasmosis transmitted by blood transfusions. Transfusion 18: 329-32, 1978.

81. TALICE, R.V.; GURRI, J.; ROYAL, J. \& PEREZMOREIRA, L. - Investigaciónes sobre la Toxoplasma gondii en sangre destinado a transfusión. Ann Fac Med Univers, Montevideo 42: 143-7, 1957.

82. NELSON, J.C.; KAUFFMANN, J.H.; CIAVARELLA, D. \& SENISI, W.J. - Acquired Toxoplasmic retinochoroiditis after platelet transfusions. Ann Ophtamol 21: 253-4, 1989.

83. MCDONALD, C.P.; BARBARA, J.A.J.; CONTRERAS, M. \& BROWN, S. - Provision of a panel of AntiToxoplasma-Negative blood donors. Vox Sang 57: 55-8, 1989.

84. PINHO, P.L.S.; AMATO NETO, V.; DUARTE, M.I.S.; COTRIM, J.X.; MOREIRA, A.A.B.; SANT'ANA, E.J. \& CAMPO, R. - Estudo experimental sobre possível atividade da violeta de genciana na profilaxia de transmissão de toxoplasmose por transfusão de sangue. Rev Inst Med Trop S Paulo 27: 89-94, 1985.

85. TURC, J.M. - MALARIA AND BLOOD TRANSFUSION. IN: WESTPHAL, RG; CARLSON KB \& TURC, JM (eds). Emerging global patterns in transfusion-transmitted infections. Arlington, VA (USA). AABB, 31-43, 1990.

86. WHO - The biology of malaria parasites - Technical Report Series 743, World Health Organization, Geneve, Switzerland, 1987.

87. BRUCE-CHWATT, L.J. - Transfusion malaria revisited. Trop Dis Bull 79:827-40,1982.

88. BRUCE-CHWATT, L.J. - Transfusion malaria. Bull WHO 50:337-46, 1974.

89. CHATAING, B. - Prevention du paludisme transfusionel. Rev Franc Transf Immunohematol 31:81-8, 1988.

90. BRUCE-CHWATT, L.J. - Blood transfusion and tropical disease. Trop dis Bull 69:825-62, 1972. 
91. ANDRADE, J.C.R. \& WANDERLEY, D.M.V. - Malária induzida no Estado de São Paulo, Brasil. Rev Soc Bras Med Trop 24:157-61, 1991.

92. International Forum: which are the appropriate modifications of existing regulations designed to prevent the transmission of malaria by blood transfusion, in view of the increasing frequency of travel to endemic areas? Vox Sang 52:138-48, 1987.

93. Council of Europe - Guide to the preparation, use and quality assurance of blood components. Strasbourg, p. 17, 1992.

94. SAZAMA, K. - Prevention of transfusional-transmitted malaria: is it time to revisit the standards (Editorial). Transfusion 31:786-88, 1991.

95. NAHLEN, B.L.; LOBEL, H.O.; CANNON, S.E. \& CAMPBELL, C.C. - Reassessment of blood donor selection criteria for the United States travellers to malarious areas. Transfusion 31:798-804, 1991.

96. Anonymous - BPAC considers malaria deferral, ICL Study, plasma source. Blood Bank Week 10(25):1-4, 1993.

97. CLOUDHURY, N.; JOLLY, J.G.; MAHAJAN, R.C.; DUBEY, M.L.; KALRA, A. \& GANGULY, N.K. - Selection of blood donors in malaria endemic countries. Lancet ii : 972-3, 1988.

98. SMITH, O.M.; TRAUL, D.L.; MCOLASH, L. \& SIEBER, F. - Evaluation of merocyanine 540 - sensitized photoirradiation as a method for purging malarially-infected red cells from blood. J Inf Dis 163:1312-17, 1991

99. AMATO NETO, V.; SANT'ANA, E.J.; PINHO, P.L.S.; MOURA, A.A.B.; DUARTE, M.F.S. \& CAMPOS, R. -
Estudo experimental sobre a possibilidade de prevenção da malária pós transfusional através do uso de violeta de genciana. Rev Saúde Publ São Paulo 21(6):497-500, 1987.

100. WELLS, L. \& ALA, F.A. - Malaria and blood transfusion. Lancet i:1317-1318, 1985.

101. REDDY, R.L. \& DELMASSO, A.P. - Transfusion acquired babesiosis in Minnesota - XXIst Congress, Internationa Society of Blood Transfusion (ISBT)/AABB, Los Angeles, USA. Abstract S447, pp.112, 1990.

102. MINTZ, E.D.; ANDERSON, J.F.; CABLE, R.G. \& HADLER, J.L. - Transfusion-transmitted babesiosis: a case report from a new endemic area. Transfusion 31:365-368, 1991.

103. HIRA, P.R. \& HUSEIN, S.F. - Some transfusion-induced parasitic infections in Zambia.J Hyg Epidemiol Microbiol Immunol 23:436-446, 1979.

104. WELLER, P.F.; SIMON, H.B.; PARKHIRST, B.H. \& MEDRIK, T.F. - Tourism-acquired Mansonella ozzardi microfilaremia in a regular blood donor. JAMA 240: 858$859,1978$.

105. AUBUCHON, J.B. \& DZIK, W.H. - Survival of Loa loa in banked blood. Lancet i: 647-648, 1983.

106. HAWKING, F. - The transference of Microfilaria bancrofti into natural and unnatural hosts. Ann Trop Med Parasitol 34: 121-129, 1940.

107. MAZZOTTI, L. \& POLANO, E. - A note on the survival of the microfilaria of Mansonella ozzardi. Bull WHO 16: 696-698, 1957. 